\title{
Erratum to: A new species of Caryospora Léger, 1904 (Apicomplexa: Eimeriidae) from the endangered Round Island boa Casarea dussumieri (Schlegel) (Serpentes: Bolyeridae) of Round Island, Mauritius: an endangered parasite?
}

Peter Daszak · Stanley J. Ball •

Daniel G. Streicker • Carl G. Jones •

Keith R. Snow

(C) Springer Science+Business Media B.V. 2011

Erratum to: Syst Parasitol (2011) 78:117-122

DOI 10.1007/s11230-010-9280-9

In the abstract of this paper, the specific name of the new taxon was accidentally mis-spelled. The correct spelling of this species is Caryospora durrelli, as given in the body of the paper.

The online version of the original article can be found under doi:10.1007/s11230-010-9280-9.

P. Daszak ( $\bowtie)$

EcoHealth Alliance, 460 West 34th Street, 17th Floor,

New York, NY 10001, USA

e-mail: daszak@ecohealthalliance.org

S. J. Ball

School of Life Sciences, Kingston University,

Kingston-upon-Thames, Surrey KT1 2EE, UK

D. G. Streicker

Odum School of Ecology, University of Georgia,

Athens, GA 30602, USA

C. G. Jones

Mauritian Wildlife Foundation, Black River, Mauritius

C. G. Jones

Durrell Wildlife Conservation Trust, Les Augrès Manor,

Trinity, Jersey, Channel Islands, UK

K. R. Snow

School of Health and Bioscience, University of East

London, London E15 4LZ, UK 